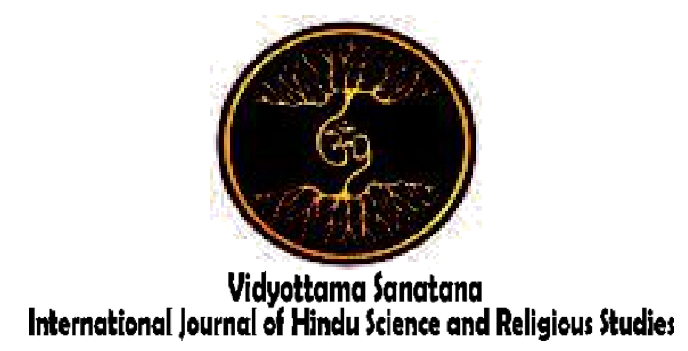

Vol. 3 No. 1 May 2019

\title{
THE FULFILLMENT OF RELIGIOUS AND CUSTOMARY RIGHTS FOR PERSONS WITH DISABILITIES IN BALI
}

\author{
By: \\ Ida Ayu Made Gayatri, Ni Kadek Juliantari \\ Universitas Ngurah Rai, STKIP Agama Hindu Amlapura \\ E-mail : dayugayatrimantra@gmail.com, kadekjuliantari755@yahoo.co.id
}

\begin{tabular}{|l|l|l|}
\hline Received: January 11, 2019 & Accepted: May 10, 2019 & Published: May 31, 2019 \\
\hline
\end{tabular}

\begin{abstract}
Religious rights of the Indonesian people have been regulated in the 1945 Constitution, Law No. 39 of 1999 concerning Human Rights. The Fulfillment of the Religious Rights of Persons with Disabilities (PD) has been regulated in article 14 of Law No. 8 of 2016 concerning Person with Disability. Protection and fulfillment of the rights of persons with disabilities is regulated in the Bali Regulation No. 9 of 2015 (Perda 9/2015).This study uses descriptive qualitative methods with a socio-normative approach related to the implementation of Perda 9/2015, identifying the challenges and opportunities of PD in Bali in obtaining their religious and customary rights. Identification is important to encourage the social inclusion and harmonization in life. Informants were selected by using purposive sampling involving disability organizations: Pertuni, Kube Darma Bakti, RwaBineda, Gerkatin, Bali Deaf Community, YBSH Foundation and Puspadi Bali. Data collection methods were observation, interview and literature study. The existence of Persons with Disability (PD) is the largest minority in the world and part of the diversity of Indonesian social and cultural structures. PD often experiences social exclusion, including in carrying out religious practices and beliefs. This discourse is often over looked because the stereotype of PD is identical with the socio-economic problems handled by the social service. Some obstacles in fulfilling the religious and belief rights of persons with disabilities: places of worship are not accessible, scarcity of religious teaching materials and lack of service facilities for PD, especially in various religious celebrations.
\end{abstract}

Keywords: Disability, Diversity, Religion 


\section{Introduction}

Religious rights in Indonesia are regulated in a number of laws and regulations. In the 1945 Constitution, article 29 concerning Religious Freedom which reads (1) the State is based on the belief in the One God; (2) The state guarantees the independence of each citizen to embrace their respective religions and to worship according to their religion and belief. Article 28E paragraph (1) of the 1945 Constitution states "Everyone is free to embrace religion and worship according to his religion, choose education and teaching, choose a job, choose citizenship, choose a place to live in the territory of the country and leave it, and have the right to return.". Article 28E paragraph (2) of the 1945 Constitution also states that everyone entitled to freedom of belief. Besides that in Article 28I paragraph (1) of the 1945 Constitution also recognized that the right to religion is a human right.

Explanation of the Decree of the President of the Republic of Indonesia No. 1 / PNPS / 1965 article 1 states that the religions embraced by the population in Indonesia are Islam, Christianity, Catholicism, Hinduism, Buddhism and Confucianism (Kon $\mathrm{Hu} \mathrm{Cu}$ ). This can be proven in the history of the development of religions in Indonesia. In Law No. 39 of 1999 the article states that religion is a human right which is stated as one of the basic principles.

The Republic of Indonesia recognizes and upholds human rights and basic human freedoms as rights that are inherently inherent and inseparable from human beings, which must be protected, respected and upheld for the enhancement of human dignity, welfare, happiness and intelligence, and justice. Chapter III Human Rights and Basic Human Freedoms in article 22 paragraph (1) Every person is free to embrace their respective religions and to worship according to their religion and belief; Paragraph (2) The State guarantees independence for everyone to embrace their respective religions and to worship according to their religion and belief.
Although freedom varies, including in human rights included in non derogable rights, or cannot be reduced under any circumstances, it does not mean absolutely all.Respect for human rights is guaranteed by the constitution and that freedom is also limited to article 28J: (1) Everyone is obliged to respect the human rights of others in the orderly life of society, nation and state; (2) In exercising their rights and freedoms, every person must comply with the restrictions stipulated by law with the sole purpose of guaranteeing recognition and respect for the rights and freedoms of others and to fulfill just demands in accordance with moral considerations, religious values, security and public order in a democratic society.

However, a number of facts show that there have been restrictions and violations of human rights for religion in various manifestations of conflict and violence such as: intolerance, discrimination, persecution in Indonesia. Religion is also most often herded as a tool of political interests to divide the nation and state. Religious conflicts in Indonesia tend to be triggered by various problems such as land disputes for places of worship, radicalism, misinterpretation of religion and blasphemy and lack of respect for harmonious living awareness. Various religious nuances in the form of physical attacks on various religious figures and persecution of religious minorities, intolerance and many other dimensions of violence that occur, indicate a serious threat to diversity (Erdianto, 2018).

In its historical journey, adherents of Confucian religion for decades experienced restrictions. In fact, as one of the religions in Indonesia, the state was recognized by the government of President Soekarno through Law No. 1 / PNPS / 1965 which was confirmed by Law number 5 of 1969 . However, during the reign of President Soeharto, an instruction was issued which banned all types of Chinese traditions, including Confucianism, in an open manner. Official recognition from the state of Confucianism came only during the reign of 
President Abdurrahman Wahid or Gus Dur in 2000 (BBC, 2001).

Setara Institute released a report related to religious intolerance throughout 2017 recorded 155 violations of freedom of religion and belief that occurred in 29 provinces in Indonesia. The violation of religious freedom is carried out by radical groups and mostly carried out by youth (Batubara, 2018). Intolerance in religious life in Indonesia still occurs in Indonesia in 2018. a number of intolerance facts such as temple destruction in Lumajang, destruction of Baiturrahim mosque in Tuban, bomb threats in the temple of Kwan Teen Koen Karawang, destruction of churches in Yogyakarta, expulsion of monks in Tangerang, attacks on scholars in Lamongan (Rohmanudin, 2018).

Human rights violations mean the loss of responsibility for protection, respect and fulfillment of the right to freedom of religion and belief means that there has been a loss of common sense, conscience, and awareness both intentionally (by commission) and or due to negligence (by ommission) (Safi'ie, 2011). Banalization of violence in the name of religion and belief means that there has been a loss of common sense, conscience, and awareness of adhering to certain religions and making the way for violence and human rights violations a habit as if there were no sins and violations in doing so.

The fulfillment of the right to religion of Persons with Disabilities in Indonesia has been regulated in Law No. 8 of 2016 and in Article 14 concerning religious rights. Bali Regulation No. 9 of 2015 concerning the protection and fulfillment of the rights of persons with disabilities in article 50 also regulates religious and customary rights. But in reality, million of person with disabilities in Indonesia and in Bali as well are socially excluded in obtaining their religious rights. People with disabilities experience various inhibiting factors besides physical limitations as well because they also face social exclusion in the form of social barriers and non-conducive infrastructure. This study focuses on opportunities and challenges for persons with disabilities to achieve fulfillment of their religious rights. Thus the issue of fulfilling religious and customary rights for persons with disabilities in Bali is relevant to be studied and discussed to achieve a common goal of creating a society that lives in harmony in diversity.

\section{Methods}

The Challenges and opportunities for fulfillment of religious and customary rights for Persons with Disabilities in Bali are qualitative research by using sociological and juridical-normative approaches. Data collection methods are obtained through observation, focused discussions (FGD) with representatives of Disability Person Organizations (DPO), and through document studies. FGDs are conducted to identify barriers and solutions for the fulfillment of inclusive religious and customary rights of persons with disabilities based on Bali Regulation (Perda 9/2015) article 50.

The Collection data is done by observation, interviews and literature studies.The implementation of social inclusion in this study was carried out by including the results of interviews in the FGD. Opinions and views of persons with disabilities are important instruments for analyzing challenges and opportunities for fulfilling religious rights for persons with disabilities.

\subsection{Sociologycal approach}

Sociology is the study of the lives of people, especially those with disabilities in Bali. This study uses a functional structuralism theoretical approach, especially in identifying social facts from religious functions and religious institutions, social actions and state obligations in fulfilling the religious rights of persons with disabilities that are inclusive.

Lubis (2015) in the Book Sociology of Religion states the function of religion, namely: 1) explaining the horizon of a world that is not accessible to humans that involves destiny and prosperity; 2) religion offers a transcendental relationship through worship and worship so as to provide an emotional 
basis for a feeling of security; 3) religion cleanses the norms and values of society that have been formed; 4) religion can also provide a standard of value in critically reassessing institutionalized norms; 5) religion performs the function of identity.

Émile Durkheim stated the function of religion as the main source of social solidarity Religious rituals that are carried out collectively can strengthen solidarity or social cohesion. Émile Durkheim defines religion as a social fact that can be identified and has social interests. For Durkheim, religion plays a functional role because religion is a principle of community solidarity (Lubis, 2015).

Society always experiences a dialectic of stability and change, integration and conflict, function and motivational power, consensus and coercion. Talcott Parsons said that every social system depends on four imperatives or problems that must be addressed so that the balance or existence of the system is guaranteed, namely: 1) adaptation; 2) the possibility of achieving goals; 3 ) integration of its members and 4) ability to maintain identity against shocks and tensions arising from within (Lubis, 2015: 53).Talcott Parsons' thinking is called an action system as a functional prerequisite for achieving balance through AGIL (Adaptation, Goal attainment, Integration and Latent pattern maintenance.

Adaptation means the necessity for the social system to deal with a good environment; Goal attainment is a functional prerequisite where action social is directed towards goals: Integration is a requirement that relates to interrelations among members in a social system, Latent pattern maintenance is a concept of latency that shows the cessation of interaction (maintenance patterns).

Talcott Parsons describes the theory of voluntary action that places individuals more as agencies than as part of structures. Subjective decisions always exist but are limited by values, norms and situations. Voluntary actions have elements such as: (1) actors or individuals; (2) purpose; (3) a set of alternatives; (4) the influence of values, norms and ideology; (5) subjective decisions; (6) the role of individuals as actors in integration in a system; (7) there needs to be an institutionalization of structures that regulate the pattern of relations between factors.

\subsection{The juridical-normative approach}

The juridical-normative approach uses legal material by examining theories, concepts, principles of law and legislation.

Religious Rights for Persons with Disabilities are regulated in Law No. 8 of 2016 concerning Persons with Disabilities in Chapter III concerning the Rights of Persons with Disabilities in the first general section, article 5 paragraph (1) letter (i).

The tenth part of article 14 concerning the Religious Rights for persons with disabilities which includes: a) embracing their respective religions and beliefs and worshiping according to their religion and belief; b) Obtain easy access in utilizing places of worship; c). Obtain holy books and other religious literature that are easily accessible based on their needs; d) obtain services in accordance with the needs when conducting worship according to their religion and belief; and e). play an active role in religious organizations.

Religious rights for persons with disabilities are based on: a. respect for dignity; b. individual autonomy; c. without discrimination; d. full celebration; e. human and human diversity; f. chance; g. equality; h. Accessibility; I. growing capacity and identity of children; j. inclusive; k. Special treatment and more pretection

In Law No. 8 of 2016 the government and regional governments carry out rehabilitation as follows: a. Protecting Persons with Disabilities from anywhere to embrace religion and belief (article 78); b. Conduct religious training and counseling on persons with disabilities (article 79); c. Encourage and / or help households provide facilities and infrastructure that are easily accessible to persons with disabilities (article 80); d. Providing scriptures and other literature that 
can be accessed through the needs of persons with disabilities (article 81); e.The Government and the Regional Government seek the availability of sign language translators in worship activities (article 82).

In Article 18 of the International Covenant on Civil and Political Rights or International Covenant on Civil and Political Rights (ICCPR) which is contained in Law Number 12 of 2005 concerning the Ratification of the Convention on Civil and Political Rights. Article 18 makes a distinction by looking at its dimensions, namely distinguishing freedom of religion or belief, and the freedom to practice religion or belief.

This distinction is based on the rationality that, first, the individual dimension reflected in the protection of one's spiritual existence (forum internum), including in this dimension, is choosing, replacing, adopting, and embracing religion and belief. Second, the collective dimension is reflected in the protection of one's existence to expel its spiritual existence and maintain it in public (forum externum) (Ratnaningsih, 2017).

Based on Law No. 28 of 2002 concerning Buildings, stipulates that each building must provide facilities/infrastructure for persons with disabilities except private housing. In addition, there is Government Regulation No. 43 of 1998 concerning Efforts to Improve Social Welfare for Persons with Disabilities.

The regulation stipulates that every provider of public facilities and infrastructure must provide equal accessibility. Accessibility is intended to create conditions and environments that support people with disabilities to socialize with the community.

This study traces the approach of Human Rights (HAM) which has been regulated in the 1945 Constitution as in article $28 \mathrm{E}$ paragraph 2 which states that everyone has the right to freedom of belief.And in Article 28I paragraph (1) of the 1945 Constitution also recognizes that religious rights are human rights. Article 29 of the 1945 Constitution concerning the Right to
Freedom of Religion, in paragraph (2) states that the state guarantees the independence of every citizen to embrace religion.

This study focuses on Bali Regional Regulation No. 9 of 2015 concerning Protection and Fulfillment of the Rights of Persons with Disabilities. In the sixth part of article 50 regulates religious and customary rights which reads (1) Every Person with Disabilities has the same rights and opportunities in carrying out religious and customary activities. (2) The Governor facilitates the availability of accessible facilities to support Persons with Disabilities in carrying out religious and customary activities independently; (3) Further provisions concerning the provision of facilities as referred to in paragraph (2), are regulated in the Governor's Regulation.

\subsection{Persons with Disabilities}

The term persons with disabilities or Penyandang Disabilitas is a substitute from penyandangcacator handicap. In Law No. 4 of 1997 concerning Handicap People stated that handicap people are any person who has a physical and / or mental disorder, which can interfere or constitute an obstacle and a barrier for him to do it properly which consists of: a. Physically disabled; $b$. Mentally disabled people; c. People with physical and mental disabilities.

In Chapter I General Provisions of Act No. 8 of 2018 concerning Persons with Disabilities states that people with disabilities are anyone who experiences physical, intellectual, mental, and / or sensory limitations in the long term who interact with the environment can experience obstacles and difficulties in participating full and effective with other citizens based on their equal rights.

This change in paradigm places persons with disabilities as no longer an issue referred to as individual problems and as a cause of barriers to activities or decent living. A paradigm shift about persons with disabilities as part of human rights that places every individual with a disability, the 
promotion and fulfillment of human rights from the state (Ratnaningsih, 2016)

In Chapter I general provisions of Bali Regional Regulation No. 9 of 2015 concerning protection and fulfillment of the rights of persons with disabilities, it is stated that persons with disabilities are everyone who has a disorder, disorder, and / or loss of physical, mental, intellectual and sensory organ functions for a long time which can prevent full and effective participation in society based on equality with others.

Article 3 pragraph 2 states the scope of types of people with disabilities includes: a. visual impairment; b. hearing disorders;c. speech disorders;d. motor and mobility disturbances;e. cerebral palsy;f. attention deficit and hyperactivity disorders;g. autism;h. epilepsy;i. tourette's syndrome; j. social, emotional, and behavioral disorders; $\mathrm{k}$. mental retardation; and l. learning delay.

Balinese people have some terms related to forms of disability in their Balinese languages such as: bongol (deaf), kolok(disability to speak), buta, peceng, picek(blind), perot (limping), rumpuh (paralyzed), sengkok (non-straight hands), buduh(mental disorder), longor (idiot), ologologan (below average intelligence). Bengkala Village in Singaraja Bali is known as the Kolok Village there are 42 people having disability with speech and deaf and the community called it as kolok.

\subsection{Religious and Customary Rights}

Religion is a system that regulates the system of faith, belief, and worship of the almighty God and the rules relating to human association with humans and the environment. Religion means qualities that are in religion or something about religion. In the Indonesian Language Dictionary, religion is defined as adhering to religion, obeying religion, worshiping.

Adat comes from Arabic which means habit. Adat or custom can be defined as actions that are done repeatedly and then become a fixed and respected habit. Adat is a habit that grows and forms from a society or area that is considered to have value, upheld and obeyed by the supporting community. Adat in Bali is regulated in customary rules in each village called awig-awig in which the implementation is adjusted according to place (desa), time (kala) and situation and condition (patra) from each village. Religious and customary rights for Person with disability in Bali are regulated in Bali Regulation (Perda Bali) No. 9 of 2015 in article 50 .

\subsection{Data Sources}

Informants as the primary data source were selected by purposive sampling, those who actively involved in the activities, leadership and organizational representation. Leaders from Organization of Person with Disability (OPD) in Bali involved in this FGD were : 1) DPD Pertuni Bali represented by I GedeWinaya (Chairman), I Made Sukawijaya (Vice Chairman) and I Nyoman Soma (Beaureu Chief of religion, art and culture); 2) Deperda Pertuni Bali represented by I Nyoman Bawa (chairman); 3) Kube Darma Bakti represented by I KetutMasir (chairman); 3) Gerkatin Bali represented by Kuswahyuhadi (chairman), Gerkatin Denpasar represented by MusantaraYudha as Chairman and Adi Negara as secretary. Puspadi Bali represented by I NengahLatra (Director) and Yayasan Bhakti SenangHati represented by I NyomanSukadana (chairman).

Pertuni stands for Indonesian Blind Union. Gerkatin stands for Indonesian Deaf Welfare Movement. DPD Pertuni Bali, DeperdaPertuni Bali and KubeDarmaBakti are organizations for blind people. Puspadi Bali and Yayasan Bhakti SenangHatiare physical disability organization. 
Data collection on people with disabilities is still a challenge in the development of inclusion. Data on people with disabilities are often not comprehensive and updated both from their names and their disabilities including the absence of data at the village government level and the absence of baseline data at the national level (Nurjanah and Fitra, 2018). Bali Regional Regulation No. 9 year 2015 is an important sourcessupported by information from research and articles that give understanding of the needs of people with disabilities in Bali.

\section{Result And Discussion}

Identification of Challenges and Opportunities for Fulfillment of Religious and Customary Rights For persons with disabilities in Bali as contained in article 50 of Perda 9 of 2015 can be delivered as follows:

\subsection{Challenges}

The existence of people with disabilities is part of the diversity of Indonesian society and also Balinese. However, the potential for persons with disabilities tends to be less developed due to physical limitations and psychological barriers other than due to environmental factors.

Persons with disabilities face barriers in integrating with society, such as social barriers, cultural and ethnic barriers, as well as architectural barriers, so that people with disabilities do not have access to life as members of the community others (Surwanti, 2013).

Low self-esteem also affects the ability to socialize and interact with the surrounding environment and other people and of course affect the level of happiness (Karyanta, 2013).Persons with disabilities are vulnerable groups who tend to be excluded in various social lives. They are excluded because of the poverty factor that makes disability a cause as well as a result of poverty. Persons with disabilities tend to be excluded in the world of work, from social networks because their family tends to be hidden by the family, the physical environment and services both public and private services (Maftuhin, 2017).

The negative stigma against Persons with Disabilities in Indonesia still occurs. Persons with Disabilities are labeled as individuals who do not have the ability and tend to be regarded as a burden to the surrounding environment. These policies and laws are still dominated and influenced by a charitable approach rather than a human rights-based approach (Ra'is, 2017).

Persons with disabilities still face discrimination, especially in women and children. They face double discrimination because of their gender and disability. Their existence tends to be isolated because there are also hidden by the family by confining them at home.

Persons with disabilities are identical with social problems and social assistance so that they are identical with the tasks of the social service. Whereas in reality, the problems faced are quite complex including in carrying out religious and customary life so that it requires cross-sector participation.

The need for persons with disabilities to be religious and involved in the participation of indigenous life is still seen as nonfundamental. Whereas religion is a basic right and human rights. The practice of Hinduism in Bali is difficult to separate the practice of religion and adat because it is often a unity of action.

Challenges faced by Persons with Disabilities to get religious and customary rights are discrimination, lack of religious books, unavailability of special services for persons with disabilities in places of worship.

Discrimination still occurs with the labeling of persons with disabilities as candala which is defined as a despicable, lowly and insulting group that limits the movement of persons with disabilities. The challenges of obtaining religious rights for persons with disabilities in Bali are as follows: 


\subsubsection{Availability of religious guide books}

The main obstacle in fulfilling religious rights for blind people is the scarcity of religious books in braille. Blind people who do not access devices and technology need religious books in braille such as spiritual songs and dharmagita. These books are playing important role as moral guide in life that they can share the moral and aesthetic value in group of hymn called pesantian.

"Qur'an and the Bible already in braille. We are Hindus and we need spiritual hymn books and darmagita as moral guides. They are important instrument for the blind. With these books blind people can contribute and be socially involved in additionto play music to accompany religious activities. So far these books have been written in braille by individual, not from publishers or religion institution."(Interviewing: I Nyoman Soma, August 27 ${ }^{\text {th }}, 2018$ ).

The obstacles that are faced mostly by deaf are that they do not understand religious texts that should be used as a reference and only pray using their own understandable language. "We don't understand mantras as they should be used. We only pray using our own words. We pray with our own words and just try to be good people by helping others. "(Interviewing: Gede Musantara Yudha, September $12^{\text {th }} 2018$ ).

\subsubsection{Special services}

Social services for persons with disabilities have not been carried out by religious institutions so that many people with disabilities only go to places of worship if there are family members or OPD organizations that are willing to take them. It is part of voluntary action held by OPD to support and serve their own member.Free services are provided for family members who are not isolated and adapt to people's lives.

The absence of services and assistance from religious institutions led to a disparity or social distance between persons with disabilities and their religion or their belief and also with religious and customary institutions. Religious institutions are passive with the presence of persons with disabilities in places of worship and customs that require special services.

"I went to a public place for worshiping at temple when I am getting old and when my children understood religious processions so they can help me. Before, I just stayed at home. Previously, residents did not allow me to be involved in celebrations because there were no special services for people with disabilities at place"(Interviewing: I Made Sukawijaya, August $27^{\text {th }}, 2018$ ).

Deaf people need empathy from religious institutions by providing special services such as a sign translator at a religious institution. "Religious leaders should be understand that we are deaf and we don't understand what they say verbally. We need signaling translators at places of worship so we don't have difficulties. Maybe there are special places of worship that can be accessed by deaf like us. "(Interviewed: Adhi Negara, 12 September 2018).

The absence of services religious institutions that should support the deaf is creating a disparity in religion practice. "I am not used to study religion anymore. Not, after I finished my school."(Interviewed: Kuswahyuhadi, September $12^{\mathrm{Th}}$,2018).

Even though according toMahasaba II PHDI 1968 (summit II held by highest administrative council of Hindu religion in 1968) stated the obligation of the priest that he as leader should actively take a apart in any meeting and discussion which is intended establish religious teachings and also give dharma upadesaor enlightenment (Sudarsana, 2018).

\subsubsection{Infrastructures}

Most religion and traditional places are not accessible to persons with disabilities. Crucial discourse about providing access for the disabled in public places, especially in places of worship, often ends up being unproductive discussions due to lack of understanding by the government and the public about people with disability. 
"The discourse of infrastructure development and accessible structures often collides with the existence of persons with disabilities. The need to build accessible infrastructure and building structures is considered as unproductive effort because the presence of persons with disabilities are rare and hardly seen in religious celebrations.

Persons with disabilities are often excluded from the environment so that their presence becomes invisible. "In the perspective of people with disabilities, they are not seen in public spaces because their presence is often hidden by families, considered as a burden and also access to worship is not accessible. This is like a debate about what was there before between chicken and eggs." (Interviewing: I NengahLatra I NengahLatra, 31 August 2018).

Infrastructure development and accessible religious structures for persons with disabilities are still far from expectations, such as lack of access to wheelchair users, narrow bathrooms, unavailability of directions for blind people. Although, in the Minister of Public Works regulation number 30 of 2006 has been regulated on the Technical Guidelines for Facilities and Accessibility in Buildings and the Environment (Robandi.2017)."Places of worship are still not disability-friendly especially for wheelchair users. "(Interviewing: I KomangSukadana, August $31^{\text {st }}$, 2018). "We were forced to carry wheelchairs on our shoulders so we could help members reach the place of worship. Whereas by providing infrastructure wheelchair users can worship independently" (Interviewing:

NengahLatra, 31 August 2018).

\subsubsection{Discrimination}

Some regions still have restrictions to prohibition to Persons with Disabilities to prayers by calling them candala. This term is understood as someone who is despicable to enter a place of worship. "My cousin is blind man as well as I am. He was forced to fight the village elite because he was forbidden to perform temple worship because of being labeled as candala and for no apparent reason. Knowing his rights, my cousin fought by threatening them that he would report it to Parisada Hindu Darma Indonesia (Indonesia Hinduism Society). Finally, my blind cousin is permitted to prayers." (Interviewing: I GedeWinaya, August 27, 2018).

Even though according to SarasammuccayaSloka40, it is stated that the priest is called Sang Apta means that he should give response, lead the follower to physical and spiritual properity and also protect his followers (Sudarsana, 2018).

\subsection{Opportunities}

Some opportunities that can be used to create a more inclusive religious life to provide protection and fulfillment of religious and customary rights for persons with disabilities are as follows:

\subsubsection{Information Technology}

Opportunities for the advancement of device technology, applications, and also social media have made it easier for blind people to access religious knowledge and education. Science and information technology not only gives pleasure that changes the order of human life, but it could become the basis of innovation on teaching hinduism and culture (Putra Yasa, etc, 2018). Learning media can stimulate motivation to learn because the interaction between students and existing learning resources (Darmaningsih.etc, 2018)

The government can publish religious material in e-book form so that it can be read with the book reader application. Many blind people have had access to devices in the form of computers and cell phones with speech applications such as jaws on computers and talks on mobile phones. But it's better for the government to synergize by helping to print in braille thespiritual songs and darmagitamade by blind people for those who don't access technology. 


\subsubsection{Accessible Buildings}

Development of infrastructure and buildings structures that are inclusive can be done by building a pilot project for accessible religious buildings such as providing wheelchair crossing portal in form S. Persons with physical disabilities can worship according to their religion and belief by using that access for themselves or be independent.

\subsubsection{Provision of Special Services}

Special services can be provided at places of worship or during religious celebrations. There needs to be a translator or sign interpreter so that deaf people can attend religious activities well. Information and directions can also be provided so that it can be accessed by persons with disabilities.

\subsubsection{Media}

Mass media and social media are productive means of channeling religious and indigenous information to people, especially persons with disabilities. The radio, television and social media become an alternative to independent religious learning.

Thus the government can carry out religious education and of course provide sign language services by using information and communication channels through mass media and social media. It is said that the communication and interaction in the stage of internalization of religious teaching is playing important role in develop good character and delivering religious values, moral values, disciplinary, communicative, aesthetic values, creative values and values of responsibility (Hiroyuki, etc, 2018).

\subsubsection{Governor Regulation}

The government issued Governor of Bali Regulation No. 67 of 2017 concerning Regional Committees to protect and fulfill the rights of persons with disabilities (disability regional committees)as independent regional institutions that have legal standing and carry out the functions of reviewing and researching, counseling and monitoring human rights and basic freedoms of persons with disabilities.

The government also issued Bali Governor Regulation No. 44 of 2018 concerning the implementing regulations of regional regulation No. 9 of 2015 concerning the protection and fulfillment of the rights of persons with disabilities. These two regulations are an opportunity to get protection and fulfillment of the right of persons with disabilities in Bali and in reducing discrimination by involving all sectors in government institutions, not only social services.

\section{Conclusion}

From the facts, social exclusion is still faced by persons with disabilities in obtaining religious rights equally and with dignity. Religious social exclusion appears in various forms such as discrimination, stereotyping, labeling as candala of despicable people who only become a social burden.

Exclusion, restrictions and restrictions on the existence of persons with disabilities in carrying out religious practices are violations of human rights. Persons with disabilities are still "the other" in religious practice

There are still many conservative elites who have not been touched by changes in the social system that occurred through the Bali Regulation No. 9 of 2015 concerning the protection and fulfillment of the rights of persons with disabilities in Bali so that discrimination is still felt.

Religious institutions are still passive in accommodating the fulfillment of the needs of persons with disabilities in obtaining their religious rights. The presence of religious leaders is more because of the invitation to give religious lectures and because they are invited by persons with disabilities.

Religious assistance is only felt in educational institutions. This social disparity makes millions of people with disabilities become an alienated society with their religion. The function of religious institutions becomes anomie when in this context religious institutions do not produce wide social solidarity.

Religious activities carried out by people with disabilities are mostly done as a form of solidarity through participation in building 
exclusive group identitiesThe fulfillment of religious and customary rights in Bali Regulation No. 9 of 2015 is an inclusive effort for the equality and dignity of persons with disabilities.

The fulfillment of religious rights is a human right that must be fulfilled by the government and also by the local government. The need for religious guidebooks, special services and sign language interpreters in religious counseling, friendly development and access of persons with disabilities are important to be carried out so as to create inclusion in a diverse society for the harmony of life. The government must also work together in cross-sector to implement Bali regulation No. 9 of 2015.The media also acts broadly in internalizing cultural and religious values in the context of inclusive society so that this should be taken into account and utilized to the fullest. Wewould like to thank all leaders from the DPOs involved in the FGD especially: DPDPertuni Bali, Deperda Pertuni Bali, Kube Darma Bakti, Gerkatin Bali Province, Gerkatin Kota Denpasar, Bali Deaf Community, Puspadi Bali, and Yayasan Bhakti Senang Hati.

\section{Reference}

Azra, Azyumardi.2016. Social Inclusion; Six Groups.Republika.co.i

Batubara, Putranegara. 2018. Upset Cases of Religious Intolerance due to Exposure to Radical Thought. Jakarta: Okezonenews. BBC.2001. State Recognition of Confucius.

Dharmaningsih, N. M. S. U., Tanu, I. K., \& Sutriyanti, N. K. (2018). Hindu Teacher Religion Learning Strategy In SMA Negeri 5 Denpasar. Vidyottama Sanatana: International Journal of Hindu Science and Religious Studies, 2(2), 252-260.

Habibie, Nur. 2018. Setara Institute: 155 cases of intolerance occurred in 2017. Merdeka.com

Hiroyuki, A., Juliawan, I. N., \& Sudarsana, I. K. (2018). Internalization Values Of Character Education Towards The
Teruna-Daha In The Medi-Median Tradition. Vidyottama Sanatana: International Journal of Hindu Science and Religious Studies, 2(2), 232-238.

ILO. 2013. Inclusion of Persons Alt Disabilities in Indonesia.

Karyanta, NugrahaArif. 2013. Self-Esteem for Person with Physical Disability jurnalwacana.psikologi.fk.uns.ac.id/ind ex.php/wacana/article/view/14/14

Maftufin, Arif. 2017. Defining Inclusive Cities: Origins, Theories and Indicators. Tata Loka Volume 19 Number 2, May 2017, 93-103 @ 2017 Planning Bureau of the Undip P ISSN 0852-7458- E ISSN 23560266.Https://www.researchgate.n et/publication/318612160_Mendefinisi kan_Kota_Inklusif_Asal Usul_Teori_Dan_Indikator

Mulia, SitiMusdah. 2007. Human Rights and Religious Freedom. Elsam: Panel Discussion: The Development of the Concept of Crimes Related to Religion in the Criminal Code

Update, the RKUHP Alliance, 2007.

Nasution, Imaduddin. 2015. Social Exclusion and Minority Study discourse. Kompasiana

Nurjanah and Fitria. 2018. Disability Data Collection is Still a Challenge in Realizing Development of Inclusion.Pattiro.or.

Ra'is, DekkiUmamur. Map of Social Inclusion In Village Regulation. Reform-ISSN 2088-7469 (Paper) ISSN 2407-6864 (Online) Volume 7 No. 2 (2017).

Ratnaningsih, Erna. 2016. Paradigm Shift on Persons with Disabilities in Law No. 8 of 2016.

2017. The Right to Freedom of Religion and Belief in the Context of Human Rights.

Ruman, YustinusSuhardi. 2014. Social Inclusion in the Jakarta Healthy Card Program (Kjs) and Jakarta Pintar Card (Kjp) in DKI Jakarta. HumanioraVol.5 No.1 April 2014: 113-121. 
https://media.neliti.com/media/publicat ions/166909-ID-inklusi-sosial-dalamprogram-kartu-jakar.pdf

Solehudin, Mochamad. 2017. How many people with disabilities are unemployed? This is whatMenaker said. Bandung: Detikfinance

Shafi'ie. 2011. Ambiguity of the Right to Religious Freedom in Indonesia and Its Position After the Decision of the Constitutional Court. Journal of the Constitution, Volume 8, Number 5, October 2011.

Sudarsana, I. K. (2018). Dharmasasananing Pandita In Hindu Diversity System In Bali. Vidyottama Sanatana: International Journal of Hindu Science and Religious Studies, 2(2), 242-251.

Rochmanudin. 2018. Cases of intolerance and religious violence Throughout 2018. Jakarta: IDN Times

Robandi.2017. Spectrum of places of worship, challenges for Indonesian architects. Yogyakarta: Solider.or.id

Erdianto, Kristian. 2018. Violence Nuances of Religion Become a Threat to Diversity. Jakarta: Kompas.com

Surwanti. Arni.2013. Model of Economic Empowerment of Persons with Disabilities at

Indonesia.journal.umy.ac.id/index.php/ $\mathrm{mb} /$ article/view/614

Suparta (2015). DPRD Special Committee mentioned Bali Disabled Persons Increased. Bali: Antara News Bali.

Tambunan, Tulus. 2016. Inclusive Economic Development, How far has Indonesia been? Jakarta: LP3ES
Winasti, Milu. 2012. Motivation for Entrepreneurship in Persons with Physical Disabilities. Empathy Vol.I No.1 December2012.

download.portalgaruda.org/article.php ?article $=123279 \&$ val $=5545$

Yasa, I. P. P., Duija, I. N., \& Wastawa, I. W. (2018). The Role Of Lontar Digitalization For Hinduism Informal Education In Preserving Cultural And Hinduism At The Puri Gede Kerambitan Tabanan. Vidyottama Sanatana: International Journal of Hindu Science and Religious Studies, 2(2), 282-286. 